\title{
FAKTOR INTERNAL DAN EKSTERNAL DALAM WHISTLE BLOWER SYSTEM
}

\author{
R. Wilopo \\ wilopo@perbanas.ac.id \\ Nurul Hasanah Uswati Dewi \\ Djuwito \\ STIE Perbanas Surabaya
}

\begin{abstract}
The research aims to observe the role of the organization of internal auditors and the witness protection agency as external factors influencing an internal auditor to be a whistle blower. The study also explores the influences of the internal auditor competencies, the moral attitude of the internal auditor and the ethical behavior of company's internal auditors as internal factors influencing an internal auditor to be whistle blower. The research samples are a hundred and one internal auditors in some corporate in Indonesia. The main method of this research is a survey research, the research done by taking a sample of the population and the use of questionnaires. The result of statistical test of the study explains that only the ethical behavior of internal auditors significantly influences a person to be a whistle blower. Although less significantly the moral attitude of the internal auditor also influences a person to be a whistle blower. While the existence of a professional organization of internal auditors, the witness protection agency, as well as the competence of the internal auditor is not considered necessary for the internal auditor to be a whistle-blower. This problem's limitation appears because in Indonesia there are not many researches observing about whistle blower, so the research model is weak. Beside that in Indonesia is not an act about whistle blower yet.
\end{abstract}

Key words: whistle blower, external factor, internal factor

\begin{abstract}
ABSTRAK
Riset ini bertujuan untuk meneliti peran organisasi profesi auditor internal serta lembaga perlindungan saksi sebagai faktor eksternal yang mempengaruhi auditor eksternal sebagai whistle blower. Riset ini juga menggali pengaruh kompetensi, sikap moral, serta perilaku etis dari auditor internal untuk menjadi whistle blower. Sampel penelitian ini sebanyak seratus satu (101) auditor internal dari beberapa perusahaan di Indonesia. Metode utama penelitian ini adalah penelitian survei, yaitu penelitian yang dilakukan dengan mengambil sampel dari populasi dan menggunakan kuisioner. Partial Least Square digunakan untuk menganalisis data penelitian. Hasil uji statistik penelitian ini menunjukkan bahwa hanya perilaku etis internal auditor yang berpengaruh signifikan bagi seseorang untuk menjadi whistle blower. Meski tidak signifikan sikap moral auditor internal juga mempengaruhi sikap seseorang untuk menjadi whistle blower. Sedangkan keberadaan organisasi profesi dari auditor internal, lembaga perlindungan saksi, serta kompetensi auditor internal tidak dianggap perlu bagi auditor internal untuk menjadi seorang whistle blower. Keterbatasan penelitian ini dikarenakan belum banyaknya penelitian tentang whistle blower di Indonesia, sehingga model penelitian ini masih lemah. Di samping itu belum adanya undang-undang whistle blower juga memberi pengaruh terhadap penelitian ini.
\end{abstract}

Kata kunci: whistle blower, faktor eksternal dan internal

\section{PENDAHULUAN}

Association of Certified Fraud Examiners (2012) menjelaskan bahwa empat puluh tiga (43) prosen kecurangan/kejahatan kerah putih diketahui karena terdapat pihak/ orang yang lapor. Lebih dari lima puluh (50) prosen dilaporkan oleh karyawan perusahaan atau organisasi tersebut. Salah 
satu profesi yang dapat memantau serta mengetahui kemungkinan terjadinya tindakan kejahatan kerah putih atau fraud adalah auditor internal (International Chamber of Commerce (ICC), 2008). Auditor internal dapat berprofesi sebagai auditor internal publik, auditor internal manajemen, maupun auditor internal pemerintah (pajak). Undang-Undang No. 20 Tahun 2001 tentang pemberantasan tindak pidana korupsi serta UU No. 8 Tahun 2010 tentang tindak pidana pencucian uang memungkinkan auditor internal untuk menyampaikan kepada pihak berwenang berbagai tindak kejahatan kerah putih atau fraud yang dilakukan oleh perusahaan termasuk manajemen perusahaan. Hal ini dikarenakan pelaku kejahatan kerah putih atau fraud melakukan tindak pidana pencucian uang tidak hanya menyimpan uang di perbankan, tetapi juga menyimpan uang dalam bentuk lain, seperti properti, valuta asing, dan berbagai aktivitas investasi lainnya (McKoy, 2012).

Dengan adanya kedua UU tersebut, maka sebagai profesi, auditor internal dapat bertindak sebagai whistle blower dalam hal pencegahan kejahatan kerah putih termasuk tindak pidana pencucian uang. Whistleblowing adalah semua upaya yang dilakukan seorang karyawan atau mantan karyawan untuk mengungkap atau menyatakan kesalahan dalam atau oleh organisasi (Das dan Aldrin, 2007). Whistle-blowing adalah kasus yang semakin umum terjadi dalam program penegakan (Heyes dan Kapur, 2009).

Namun langkah sebagai whistle blower bagi auditor internal bukanlah sesuatu yang tidak mengandung risiko. Hal ini juga menyangkut prinsip etika profesi auditor internal, khususnya yang berkaitan dengan prinsip keenam yaitu kerahasiaan.

Meski sudah ada UU tentang perlindungan saksi, auditor internal yang bertindak sebagai whistle blower juga dapat menjadi sasaran berbagai pihak yang merasa dirugikan, termasuk kemungkinan "senjata makan tuan" karena pencemaran nama baik, serta ancaman dari institusi tempat auditor internal bekerja. Oleh karenanya faktor eksternal seperti keberadaan dan peran dari organisasi profesi, serta peranan dari perlindungan saksi, sangat berperan dalam mendorong auditor internal untuk bertindak sebagai whistle blower. Selain faktor eksternal, faktor internal pribadi dari auditor internal, seperti tingkat kompetensi yang dimiliki oleh auditor internal, sikap moral auditor internal, serta perilaku etis dari auditor internal juga menentukan peran auditor internal sebagai whistle blower (Antara, 2008).

Oleh karena itu, berkaitan dengan peran auditor internal sebagai whistle blower terdapat pertanyaan dan permasalahan: Pertama, apakah faktor-faktor internal yaitu kompetensi auditor internal, sikap moral auditor, dan perilaku etis internal dapat menentukan dan memberikan pengaruh sehingga auditor internal bersedia menjadi whistle blower?. Kedua, apakah faktor-faktor eksternal yaitu peran organisasi profesi dan perlindungan saksi dapat menentukan dan memberikan pengaruh sehingga auditor internal bersedia menjadi whistle blower?

Dengan demikian tujuan penelitian ini adalah untuk: Pertama, menguji pengaruh faktor-faktor internal yaitu kompetensi auditor internal, sikap moral auditor, dan perilaku etis internal terhadap keputusan auditor internal menjadi whistle blower. Kedua, menguji faktor-faktor eksternal yaitu peran organisasi profesi dan perlindungan saksi terhadap keputusan auditor internal menjadi whistle blower.

\section{TINJAUAN TEORETIS \\ Whistle Blower}

Whistle blower adalah karyawan, mantan karyawan atau pekerja, anggota dari suatu institusi atau organisasi yang melaporkan tindakan yang dianggap melanggar ketentuan kepada pihak yang berwenang. Tindakan yang dianggap melanggar ketentuan berarti melanggar hukum, aturan, dan persyaratan yang menjadi ancaman pihak publik atau kepentingan publik. 
Whistle blower terdiri atas tipe internal whistle blower dan eksternal whistle blower. Internal whistle blower adalah seorang pekerja atau anggota suatu organisasi di dalam suatu perusahaan atau institusi yang melaporkan suatu tindakan pelanggaran hukum, aturan, dan atau persyaratan kepada karyawan lainnya atau atasannya yang ada di dalam perusahaan atau institusi tersebut, sedangkan eksternal whistle blower adalah seorang pekerja atau anggota suatu anggota organisasi di dalam suatu perusahaan atau institusi yang melaporkan suatu tindakan pelanggaran hukum, aturan, dan atau persyaratan kepada pihak luar institusi, organisasi, atau perusahaan. Biasanya eksternal whistle blower melaporkan segala tindakan pelanggaran tersebut kepada media, penegak hukum, atau pengacara, bahkan kepada agen-agen pengawas praktik korupsi ataupun institusi pemerintah lainnya.

Secara umum seorang "whistle blower" tidak akan dianggap sebagai "orang perusahaan atau institusi/organisasi" karena tindakannya melaporkan pelanggaran hukum yang dilakukan oleh pihak perusahaan atau organisasi. Secara lengkap seorang whistle blower dianggap telah menyimpang dari kepentingan perusahaan atau organisasi. Namun bila pengungkapan tersebut diminta oleh hukum atau diminta atas perintah lembaga pemerintah atau agenagen pemerintah, maka laporan whistle blower tersebut tidak dapat dianggap sebagai pengkhianatan (Mansbach, 2007). Di Amerika Serikat tidak ada kasus seorang whistle blower diadili karena dianggap sebagai pengkhianatan, apalagi bila perusahaan atau organisasi tersebut telah melakukan tindakan pelanggaran hukum.

\section{Perkembangan Whistle Blower}

Menjadi seorang whistle blower akan meningkatkan pengakuan yang berskala dunia sebagai cara penting untuk menjamin transparansi dan integritas pasar global (Dworkin, 2007). Sumbangan pihak dalam perusahaan dengan memberi informasi ten- tang hal-hal salah yang dilakukan perusahaan, khususnya di situasi yang begitu kompleks dan berbeda seperti saat ini.

Berbagai kasus kecurangan yang dilakukan oleh perusahaan-perusahaan berskala dunia di USA pada awal 2000an, seperti Enron, WorldCom, Xerox, dan lainlain memunculkan Sarbanes-Oxley Act, 2002 (SOX Act), yang mengatur antara lain mekanisme tentang whistle blower. Konggres USA pada saat tersebut menyatakan bahwa SOX Act berusaha mendorong dan melindungi whistle blower dalam berbagai cara, termasuk memberi nama samaran kepada seseorang yang menjadi whistle blower, menetapkan pinalti atau hukuman kepada seseorang atau institusi yang melakukan pembalasan dendam terhadap whistle blower. Demikian pula SOX Act memberi sarana yang jelas kemana seorang whistle blower akan menyampaikan laporan dan temuannya.

Dengan berkembangnya upaya untuk pemberantasan korupsi di Indonesia, khususnya setelah era reformasi, maka muncul dengan berbagai motif, seseorang yang "berani" dikategori sebagai whistle blower. Namun menjadi seorang whistle blower di Indonesia bukannya tanpa risiko (Tempo Interaktif, 2008). Sebagai saksi kunci, dapat mengalami tiga ancaman sekaligus. Pertama, ancaman atau intimidasi dari orang-orang yang mereka beberkan namanya. Kedua, seorang whistle blower berisiko terkena efek "senjata makan tuan" dari pengakuan dan informasi yang mereka berikan kepada media massa, lembaga antikorupsi, pengacara, atau aparat hukum lainnya. Ucapan mereka dapat dijadikan sasaran delik pencemaran nama baik, sehingga tidak jarang seorang whistle blower justru dijebloskan ke penjara. Ketiga, ancaman yang juga bakal dihadapi seorang whistle blower datang dari kalangan internal perusahaan atau institusi. Whistle blower menghadapi risiko penurunan pangkat, skorsing, intimidasi, atau diskriminasi dari institusi tempat berkarya yang merasa di- 
rugikan dan atau dipermalukan atas pelaporannya.

\section{Peran Auditor Internal sebagai Whistle Blower}

Auditor internal, baik yang bekerja di organisasi, maupun sebagai auditor internal publik, menduduki posisi yang khusus yang memberi hak istimewa atas seperangkat informasi yang secara potensial dapat menyingkap perilaku manajemen puncak yang menyimpang (yang memberi hak istimewa atas seperangkat informasi yang secara potensial harus menyingkap perilaku manajemen puncak yang menyimpang (Richardson dan Richardson, 2007). Perilaku manajemen puncak yang menyimpang dapat menyebabkan biaya ekonomi, sosial, serta emosional yang besar bagi pemangku kepentingan yang tidak bersalah serta menyebabkan kegagalankegagalan perusahaan pada dekade terakhir ini seperti yang terjadi pada akhir-akhir ini (Verschoor, 2002). Jadi, bila manajemen puncak melakukan perilaku yang menyimpang dan merugikan para pemangku kepentingan, dan para auditor internal dalam organisasi maupun auditor internal publik dapat mengidentifikasi perilaku yang tidak benar tersebut, maka para auditor internal tersebut harus lebih memihak pada kepentingan publik dengan bertindak tindakan sebagai whistle blower (Bouville, 2008). Auditor internal harus menjadi pahlawan bagi para pemangku kepentingan.

\section{Faktor-Faktor yang Menentukan Auditor Internal sebagai Whistle Blower}

Sikap dan tindakan auditor internal baik auditor internal maupun sebagai auditor eksternal dipengaruhi oleh berbagai faktor. Faktor-faktor tersebut dapat dibagi menjadi faktor eksternal pribadi auditor internal, serta faktor internal pribadi si auditor internal. Faktor eksternal tersebut dapat terdiri atas peran organisasi profesi, serta perlindungan sebagai saksi bila seorang auditor internal melakukan tindakan sebagai whistle blower. Di samping itu faktor internal pribadi auditor internal yaitu kompetensi, sikap moral serta perilaku etis dari auditor internal yang dapat mempengaruhi perilaku auditor internal sebagai whistle blower (Lezar dan Spaeth, 2002).

\section{Peran organisasi profesi}

Organisasi profesi, selain sebagai tempat untuk berorganisasi dari suatu profesi, juga merupakan pusat moral bagi para anggotanya (Saleh, 2008). Menjadi pusat moral berarti organisasi profesi berperan untuk mendorong para anggotanya untuk bertindak sebagai whistle blower bila diperlukan dan sesuai dengan ketentuan peraturan atau undang-undang yang berlaku. Organisasi profesi harus melindungi berbagai kepentingan auditor dan auditor eksternal organisasi sehingga mereka dapat berperilaku etis ataupun bertindak sebagai whistle blower (Kleckner and Jackson, 2004). Dengan demikian dapat disimpulkan bahwa semakin efektif kinerja dari organisasi profesi, maka akan semakin etis perilaku auditor internal serta semakin baik tindakan mereka di saat menjadi whistle blower.

\section{Perlindungan saksi}

Indonesia dengan dikeluarkannya Undang-Undang nomor 13 tahun 2006 telah memberi perlindungan kepada saksi (maupun korban) maupun kepada mereka yang bertindak sebagai whistle blower (UU nomor 13 tahun 2006 dan Kleckner dan Jackson, 2004). Dengan demikian, semakin terdapat ketentuan perlindungan sebagai saksi, maka semakin auditor internal akan berperilaku etis, serta semakin besar niat mereka untuk menjadi whistle blower.

\section{Kompetensi Auditor internal}

Seorang yang memperoleh pendidikan auditor internal dan gelar auditor internal, tentunya melalui proses yang panjang dan memerlukan ketekunan tersendiri (Baker, 2008). Dalam proses sebagai seorang profesional, seorang auditor internal, khususnya auditor internal publik diwajibkan untuk memperoleh satuan kredit 
profesi setiap tahunnya. Satuan kredit profesi ini lazimnya berupa penyegaran maupun penambahan pengetahuan oleh organisasi (Institut Akuntan Publik Indonesia (IAPI), 2009). Dengan peningkatan kompetensi secara terus menerus dan berkesinambungan, maka auditor internal diharapkan memiliki kepribadian yang akan bersikap etis bila mengetahui tindak kejahatan kerah putih atau fraud. Dengan demikian dapat disimpulkan bahwa semakin tinggi kompetensi seorang auditor internal, akan semakin mereka bersedia menjadi seorang whiste blower.

\section{Sikap Moral Auditor Internal}

Integritas merupakan nilai-nilai yang sangat diperlukan dan dimiliki oleh auditor internal. Dengan integritas, maka auditor internal akan semakin bertindak jujur, adil, serta berpegang secara terus menerus pada kode etik profesi auditor internal (Media Pertamina, 2008). Salah satu pengukur dari integritas auditor internal adalah sikap moral auditor internal. Pengukuran sikap moral auditor internal ini dapat menggunakan model pengukuran moral yang di- kembangkan oleh Kohlberg (1969) dan Rest (1979) dalam bentuk instrumen Defining Issues Test. Dengan demikian semakin tinggi sikap moral auditor internal, maka semakin besar pula kemauan mereka untuk menjadi seorang whistle blower.

\section{Perilaku Etis Auditor internal}

Wilopo (2006) menemukan bahwa perilaku etis atau tidak etis dari auditor internal akan memberikan pengaruh terhadap kecenderungan kejahatan yang dilakukan oleh para auditor internal dalam bentuk kecurangan auditor internal. Sebaliknya, perilaku etis adalah perilaku yang tidak menyalahgunakan kedudukan/posisi, perilaku yang tidak menyalahgunakan kekuasaan, perilaku yang tidak menyalahgunakan sumber daya organisasi, serta perilaku yang peduli terhadap kondisi perusahaan (Robinson dan Bennet, 1995; Tang dan Chiu, 2003). Dengan demikian, semakin tinggi perilaku etis seorang auditor internal, semakin besar kemauan mereka untuk menjadi whistle blower. Rerangka konseptual penelitian disajikan dalam gambar 1 berikut ini.

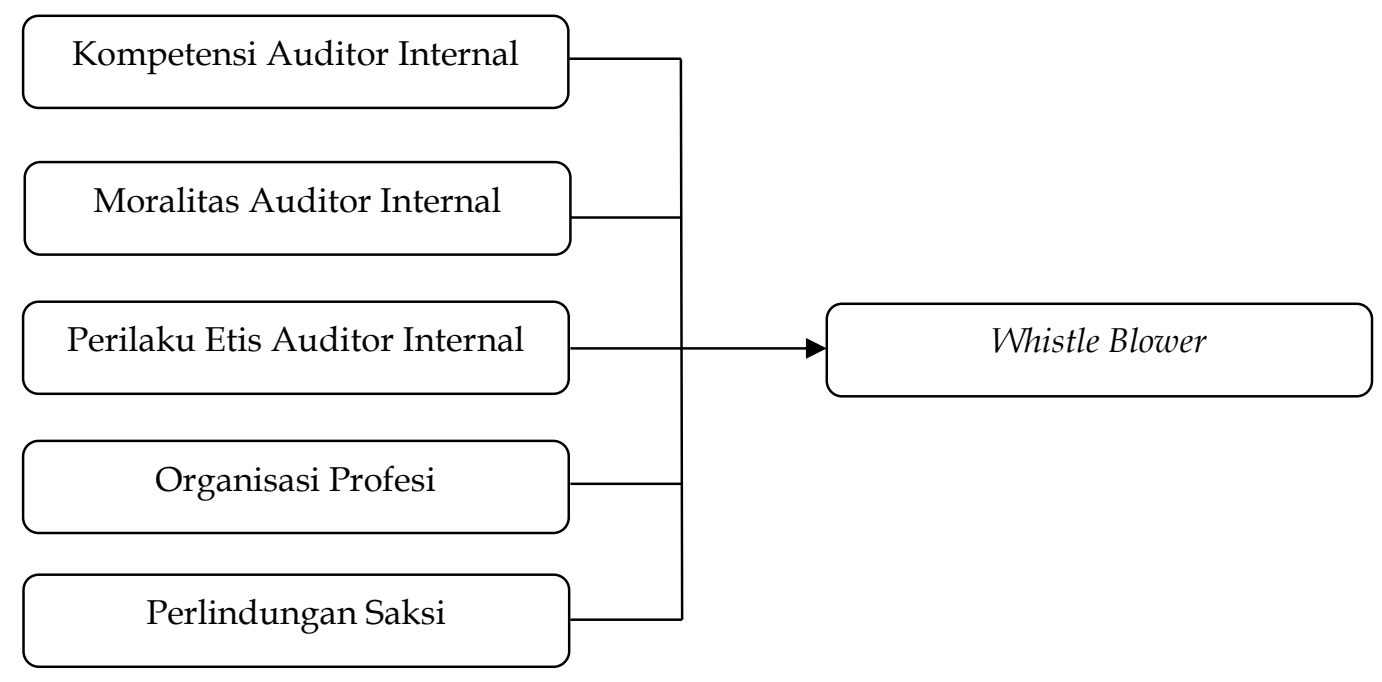

Gambar 1

Rerangka Konseptual 
Berdasarkan rerangka konseptual tersebut, dapat dirumuskan hipotesis penelitian sebagai berikut:

$\mathrm{H}_{1}$ : Semakin tinggi kompetensi auditor internal, maka semakin besar keinginan dan kemauan auditor internal untuk menjadi whistle blower

$\mathrm{H}_{2}$ : Semakin tinggi tingkat moralitas auditor internal, maka semakin besar keinginan dan kemauan auditor internal untuk menjadi whistle blower

$\mathrm{H}_{3}$ : Semakin tinggi perilaku etis auditor internal, maka semakin besar keinginan dan kemauan auditor internal untuk menjadi whistle blower

$\mathrm{H}_{4}$ : Semakin besar peran organisasi profesi dalam menata perilaku auditor internal, maka semakin besar keinginan auditor internal untuk menjadi whistle blower

$\mathrm{H}_{5}$ : Semakin terdapat perlindungan saksi kepada auditor internal, maka semakin besar keinginan dan kemauan auditor internal untuk menjadi whistle blower

\section{METODE PENELITIAN Pendekatan Penelitian}

Penelitian ini merupakan pengembangan dari penelitian Wilopo dan Nurul (2012). Pengembangan yang dilakukan adalah dengan memperluas cakupan penelitian yang dahulunya mencakup wilayah Jawa Timur menjadi seluruh Indonesia. Penelitian ini bertujuan menguji secara empiris pengaruh peran organisasi profesi, perlindungan saksi, kompetensi auditor internal, sikap moral auditor internal, perilaku etis auditor internal serta peran auditor internal terhadap whistle blower. Rancangan penelitian ini merupakan rancangan penelitian kausal (causal studies) (Cooper dan Emory, 1995). Hal ini karena penelitian ini bermaksud meneliti faktor-faktor yang mempengaruhi peran auditor internal sebagai whistle blower.

Penelitian ini juga disebut penelitian penjelasan (explanatory research), karena tujuannya adalah untuk menjelaskan pengaruh antar variabel melalui pengujian hipotesis (Malhotra, 2010). Metode utama penelitian ini adalah penelitian survei, yaitu penelitian yang dilakukan dengan mengambil sampel dari populasi dan menggunakan kuisioner sebagai alat pengumpulan data pokok.

\section{Populasi dan Sampel}

Penelitian ini dilakukan di seluruh Indonesia. Hal ini dikarenakan populasi penelitian adalah para auditor internal, yaitu auditor internal yang bekerja di perusahaan-perusahaan yang berada di Indonesia.

Mengingat perilaku etis dan kemauan untuk menjadi whistle blower merupakan nilai-nilai yang dimiliki oleh para auditor internal yang bekerja di perusahaan, maka populasi penelitian ini adalah para auditor internal yang bekerja di berbagai perusahaan di Indonesia. Mengingat auditor internal di Indonesia memiliki organisasi profesi, maka auditor internal yang diambil sebagai sampel adalah para auditor internal yang tergabung dalam Forum Komunikasi Satuan Pengawasan Internal (FKSPI).

\section{Teknik dan Prosedur Pengumpulan Data}

Pengumpulan data dalam penelitian ini dilakukan dengan teknik dan prosedur sebagai berikut: a) Kuesioner. Kuesioner merupakan satuan model yang di dalamnya berisi beberapa pertanyaan atau pernyataan yang berhubungan dengan variabel-variabel penelitian. Pernyataan peneliti dan jawaban responden dikemukakan secara tertulis melalui kuesioner. Setelah kuesioner diberikan kepada responden untuk kemudian diisi dan dikembalikan, tahap selanjutnya adalah mengevaluasi kuesioner yang telah dikumpulkan kembali untuk menyeleksi apakah kuesioner tersebut diisi lengkap dan layak digunakan sebagai data penelitian. b) Wawancara. Wawancara merupakan teknik pengumpulan data dalam metode survei yang menggunakan pertanyaan secara lisan kepada subyek penelitian. Wawancara digunakan untuk memperoleh informasi secara langsung dari 
responden untuk melengkapi hal-hal yang diperlukan dalam penelitian. Jenis data yang digunakan adalah data kualitatif yang dikuantifisir, yaitu data penelitian yang berbentuk kualitatif yang diangkakan (skoring).

\section{Variabel dan Definisi Operasional Varia- bel Penelitian \\ Klasifikasi Variabel Penelitian}

Kerlinger (1986) menyatakan bahwa variabel adalah konstruk atau sifat yang akan dipelajari. Oleh karena itu variabel dikelompokkan berdasar sifat pengukurannya atau dapat tidaknya suatu variabel diukur secara langsung atau harus ditaksir melalui indikator-indikatornya. Dengan demikian maka variabel tersebut dapat dikelompokkan menjadi variabel independen dan variabel dependen dengan pemahaman masing-masing variabel sebagai berikut: Variabel independen yaitu variabel yang memberi pengaruh terhadap peran auditor internal sebagai whistle blower. Variabel tersebut adalah kompetensi auditor internal, sikap moral auditor internal, perilaku etis auditor internal, keberadaan dan peran organisasi profesi, serta perlindungan saksi, sedangkan variabel dependen yaitu variabel yang dipengaruhi oleh variabel independen, yaitu peran auditor internal sebagai whistle blower.

\section{Definisi Operasional Variabel Penelitian}

\section{Whistle blower}

Whistle blower adalah karyawan, mantan karyawan atau pekerja, anggota dari suatu institusi atau organisasi yang melaporkan suatu tindakan yang dianggap melanggar ketentuan kepada pihak yang berwenang. Respon responden diukur dengan skala Likert 1-5.

2. Peran organisasi profesi

Organisasi profesi adalah kumpulan dari orang profesional. Organisasi tersebut lazimnya memiliki kode etik organisasi, sehingga peran organisasi profesi dapat diartikan sebagai peran dari organisasi profesi untuk mengatur dan melindungi kepentingan anggotanya, khususnya dalam menghadapi dilema etika. Respon responden diukur dengan skala Likert 15.

3. Perlindungan saksi

Perlindungan saksi adalah perlindungan yang diberikan kepada seseorang yang dapat memberi keterangan guna kepentingan penyelidikan, penyidikan, penuntutan, dan pemeriksaan di sidang pengadilan tentang suatu perkara pidana yang ia lihat sendiri dan/atau ia alami sendiri (UU No. 13 tahun 2006). Respons responden diukur dengan skala Likert 15.

4. Kompetensi Auditor internal

Kompetensi auditor internal adalah keahlian yang dimiliki auditor internal yang diperoleh melalui pendidikan dan pengalaman. Kompetensi profesional dibagi menjadi dua (2) fase terpisah, yaitu 1) pencapaian kompetensi profesional dan 2) pemeliharaan kompetensi profesional (Ikatan Auditor Internal Indonesia, 1998). Respon responden diukur dengan skala Likert 1-5.

5. Sikap Moral Auditor Internal

Pengukuran moralitas manajemen berasal dari model pengukuran moral yang dikembangkan Kohlberg (1969) dan Rest (1979) dalam bentuk instrumen Defining Issues Test. Instrumen ini berbentuk kasus dilema etika. Moralitas manajemen diukur melalui 6 (enam) butir instrumen yang mengukur setiap tahapan moralitas manajemen melalui kasus dilema etika auditor internal. Hasil pengukuran atas dilema etika auditor internal ini merupakan cerminan moralitas manajemen perusahaan.

6. Perilaku Etis Auditor Internal

Perilaku etis auditor internal diukur dengan instrumen yang dikembangkan Robinson dan Bennet (1995) dan Tang dan Chiu (2003) dan diukur dengan empat item pertanyaan. Respon responden diukur dengan skala Likert 1-5. 


\section{Teknik Analisis Data}

Uji validitas dilakukan pada validitas item-item pertanyaan dalam kuesioner. Pengujian dilakukan dengan cara menghitung korelasi antara skor masing-masing item pertanyaan dengan skor total. Suatu kuesioner dikatakan valid apabila pertanyaan pada kuesioner mampu mengungkap sesuatu yang akan diukur oleh kuesioner tersebut atau dikatakan valid jika probabilitasnya kurang dari 0,05 atau $\mathrm{r}$ hitung lebih besar dari $\mathrm{r}$ tabel dan bernilai positif. Uji validitas ini dilakukan dengan bantuan komputer dengan menggunakan konsep korelasi Product Moment dari Pearson (Ghozali, 2012).

Penelitian ini menggunakan teknik analisis kuantitatif. Dalam penelitian ini, analisis kuantitatif dilakukan dengan cara mengkuantifikasi data-data penelitian sehingga menghasilkan informasi yang dibutuhkan untuk analisis data. Sebelum diolah, data yang sudah terkumpul harus dilakukan Purification dan Refinement dengan melakukan evaluasi terhadap validitas dan reliabilitas konstruk berdasarkan level abstraksi dengan menilai convergent validity dan discriminant validity serta evaluasi goodness of fit model (Ghozali, 2012). Proses tersebut dilakukan dengan bantuan software Smart PLS 2.0 dan data yang telah terkumpul direkap dalam format Comma Delimited. Software Smart PLS digunakan karena setiap variabel penelitian memiliki indikator-indikator.

\section{ANALISIS DAN PEMBAHASAN Gambaran Subyek Penelitian}

Penelitian ini mengambil responden auditor internal dalam perusahaan (Satuan Pengawasan Internal). Sebelum dilakukan penyebaran kuesioner, dilakukan Focus Group Discussion (FGD) mengenai instrumen penelitian. FGD dilakukan pada pengurus Forum Komunikasi Satuan Pengawasan Internal (FKSPI). Teknik pengambilan data dilakukan dengan mengikuti penyebaran kuesioner pada para anggota auditor internal di seluruh perusahaan Indonesia yang tergabung dalam Forum Komunikasi Satuan Pengawasan Internal (FKSPI). Responden yang didapat adalah sebagai berikut: (1) Perolehan kuesioner melalui FKSPI Seminar Whistle Blower System sebanyak 30 Kuesioner dan (2) Perolehan kuesioner melalui Musyawarah Nasional FKSPI sebanyak 71 Kuesioner sehingga total kuesioner yang masuk dan diolah sebanyak 101.

Karakteristik responden berdasarkan jenis kelamin terdiri atas laki-laki sebanyak 83 orang dan perempuan sebanyak 16 orang, sedangkan 2 orang tidak menyebutkan jenis kelaminnya. Berdasarkan karakteristik responden berdasarkan lama bekerjanya terdiri atas 1-5 tahun sebanyak 13 orang, 6-10 tahun sebanyak 6 orang, $>10$ tahun sebanyak 77 orang, dan sebanyak 5 orang tidak menyebutkan lama bekerjanya di perusahaan.

\section{Analisis Data}

\section{Analisis Model Pengukuran}

Analisis ini digunakan untuk mengetahui tingkat validitas dan reliabilitas masingmasing indikator dan konstruk. Tahap dalam analisis model pengukuran ini yaitu:

a. Analisis Validitas Konvergen (Convergent Validity)

1. Validitas konvergen dapat diketahui dengan melihat nilai dari loading factor, reliabilitas konstruk, dan AVE dan disajikan dalam gambar 2 . Berdasarkan gambar 2, nilai loading factor yang dihasilkan oleh data tersebut sudah memenuhi syarat validitas yaitu $>0.5$ sehingga data tersebut dapat dikatakan valid dan siap untuk dilakukan proses se lanjutnya yaitu menguji signifikansi loading factor dengan $\mathrm{t}$ statistic.

2. Tahap berikutnya ini dilakukan dengan melakukan boothstrapping yang menghasilkan nilai $\mathrm{t}$ statistic. 
Tabel 1

Outer Loadings (Mean, STDEV, T-Values)

\begin{tabular}{|c|c|c|c|c|c|}
\hline & $\begin{array}{c}\text { Original } \\
\text { Sample }(\mathrm{O})\end{array}$ & $\begin{array}{c}\text { Sample } \\
\text { Mean }(M)\end{array}$ & $\begin{array}{c}\text { Standard } \\
\text { Deviation } \\
\text { (STDEV) }\end{array}$ & $\begin{array}{c}\text { Standard } \\
\text { Error } \\
\text { (STERR) } \\
\end{array}$ & $\begin{array}{c}\text { T Statistics } \\
(|O / S T E R R|)\end{array}$ \\
\hline KPS10 <- KPS & 0.856099 & 0.833295 & 0.076498 & 0.076498 & 11.191203 \\
\hline KPS11 <- KPS & 0.859401 & 0.850026 & 0.063453 & 0.063453 & 13.543933 \\
\hline KPS12 <- KPS & 0.883351 & 0.872660 & 0.059119 & 0.059119 & 14.942037 \\
\hline KPS13 <- KPS & 0.930689 & 0.907183 & 0.074801 & 0.074801 & 12.442274 \\
\hline KPS14 <- KPS & 0.731693 & 0.705555 & 0.128323 & 0.128323 & 5.701978 \\
\hline MA15 <- MA & 0.906893 & 0.871863 & 0.166499 & 0.166499 & 5.446852 \\
\hline MA16 <- MA & 0.883735 & 0.846901 & 0.173362 & 0.173362 & 5.097619 \\
\hline MA17 <- MA & 0.899670 & 0.867514 & 0.169243 & 0.169243 & 5.315836 \\
\hline MA18 <- MA & 0.822905 & 0.792538 & 0.166889 & 0.166889 & 4.930841 \\
\hline MA19 <- MA & 0.611964 & 0.587196 & 0.177651 & 0.177651 & 3.444743 \\
\hline MA20 <- MA & 0.769618 & 0.743290 & 0.152795 & 0.152795 & 5.036934 \\
\hline PES6 <- PES & 0.907820 & 0.906878 & 0.052049 & 0.052049 & 17.441670 \\
\hline PES7 <- PES & 0.957981 & 0.944134 & 0.040206 & 0.040206 & 23.826603 \\
\hline PES8 <- PES & 0.944451 & 0.927958 & 0.050276 & 0.050276 & 18.785184 \\
\hline PES9 <- PES & 0.913796 & 0.895238 & 0.063615 & 0.063615 & 14.364571 \\
\hline POP1 <- POP & 0.898262 & 0.875515 & 0.071043 & 0.071043 & 12.643879 \\
\hline POP2 <- POP & 0.917757 & 0.900892 & 0.053394 & 0.053394 & 17.188417 \\
\hline POP3 <- POP & 0.838191 & 0.828839 & 0.053170 & 0.053170 & 15.764448 \\
\hline POP4 <- POP & 0.842789 & 0.826595 & 0.076353 & 0.076353 & 11.038122 \\
\hline POP5 <- POP & 0.821899 & 0.812735 & 0.062716 & 0.062716 & 13.105020 \\
\hline PS10 <- PS & 0.921077 & 0.905700 & 0.048703 & 0.048703 & 18.912206 \\
\hline PS6 <- PS & 0.875063 & 0.858234 & 0.095326 & 0.095326 & 9.179639 \\
\hline PS7 <- PS & 0.979208 & 0.971150 & 0.043280 & 0.043280 & 22.625023 \\
\hline PS8 <- PS & 0.951441 & 0.938554 & 0.050277 & 0.050277 & 18.923989 \\
\hline PS9 <- PS & 0.944560 & 0.935022 & 0.039667 & 0.039667 & 23.812031 \\
\hline WB1 <- WB & 0.835877 & 0.823338 & 0.056022 & 0.056022 & 14.920526 \\
\hline WB2 <- WB & 0.792558 & 0.758320 & 0.125416 & 0.125416 & 6.319449 \\
\hline WB3 <- WB & 0.755210 & 0.736713 & 0.115219 & 0.115219 & 6.554571 \\
\hline WB4 <- WB & 0.786337 & 0.771648 & 0.070511 & 0.070511 & 11.151989 \\
\hline WB5 <- WB & 0.714700 & 0.697156 & 0.141047 & 0.141047 & 5.067088 \\
\hline
\end{tabular}




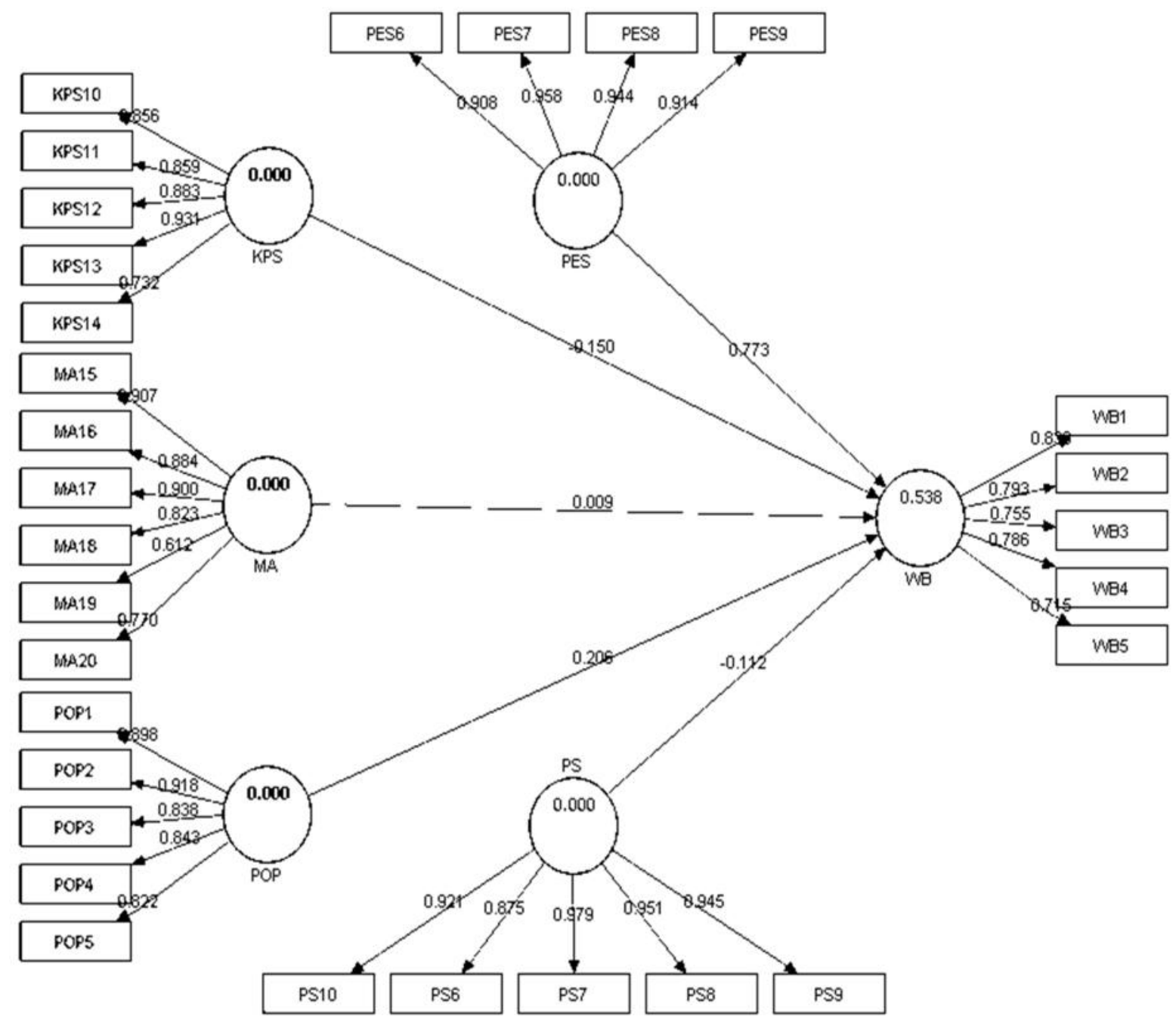

Gambar 2

Uji Validitas Konvergen

Berdasarkan hasil analisis, nilai $\mathrm{t}$ statistic masing-masing loading factor disajikan dalam tabel 1 dan menunjukkan angka > 1.96 sehingga data-data tersebut memiliki validitas yang signifikan.

3. Tahap selanjutnya yaitu mengukur tingkat validitas dan reliabilitas. Untuk menguji reliabilitas konstruk tersebut dilakukan dengan melihat Composite Reliability. Dalam penelitian ini, standar yang digunakan untuk menilai apakah data yang terkumpul reliabel atau tidak yaitu > 0.7. Dari output yang dihasilkan dalam tabel 2, masing-masing kons- truk telah menunjukkan angka di atas 0.7 sehingga dapat dikatakan bahwa data reliable.

Tabel 2

Composite Reliability

\section{Composite Reliability}

\begin{tabular}{cl}
\hline KPS & 0.930957 \\
MA & 0.924980 \\
PES & 0.963115 \\
POP & 0.936608 \\
PS & 0.971957 \\
WB & 0.884339 \\
\hline
\end{tabular}


4. Selanjutnya melihat nilai AVE. Hal ini dimaksudkan untuk melihat apakah data tersebut telah valid atau belum. Standar yang digunakan untuk mengukur tingkat validitas yaitu nilai AVE > 0.5. Data semua kontruk dalam tabel 3 menunjukkan bahwa nilai AVE > 0.5 sehingga dapat dikatakan memenuhi syarat validitas konvergen.

Tabel 3

AVE

\begin{tabular}{cc}
\hline \hline & AVE \\
\hline KPS & 0.730668 \\
MA & 0.676139 \\
PES & 0.867219 \\
POP & 0.747506 \\
PS & 0.874080 \\
WB & 0.605260 \\
\hline
\end{tabular}

\section{b. Analisis Validitas Diskriminan} (Discriminant Validity)

Selanjutnya dilakukan analisis atas validitas diskriminan. Dalam analisis ini terdapat 2 tahap yaitu: Pertama, melihat cross loading. Pada hasil cross loading setiap konstruk sudah menunjukkan angka korelasi yang lebih tinggi dengan masing-masing indikatornya, sehingga dapat dikatakan bahwa konstruk mampu menjelaskan varian pada setiap indikatornya lebih tinggi jika dibandingkan dengan indikator konstruk lainnya. Dapat disimpulkan bahwa data tersebut memiliki validitas diskriminan yang baik sebagaimana disajikan dalam tabel 4. Kedua, membandingkan korelasi antar konstruk dengan akar kuadrat AVE Korelasi maksimal konstruk KPS yaitu 0.854251; sedangkan akar AVE yaitu sebesar 0.854791. Konstruk MA memiliki korelasi maksimum sebesar 0.704937; sedangkan akar AVE yaitu 0.822277 . Selengkapnya, setiap konstruk memiliki nilai akar AVE lebih besar dari korelasi maksimal antar konstruk. Maka, secara umum semua indikator telah memiliki validity discriminant yang baik dalam menyusun variabel-variabelnya sebagaimana disajikan dalam tabel 5.

\section{c. Analisis Model Struktural}

Model struktural dalam PLS diukur dengan menggunakan $\mathrm{R}^{2}$ untuk variabel dependen dan koefisien path yang ditunjukkan dengan $\mathrm{t}$ statistic untuk menguji signifikansi hipotesis dan nilai $\mathrm{R}^{2}$. Skor koefisien path yang ditunjukkan dengan $\mathrm{t}$ statistic memiliki standar 1.96.

1. Analisis R-square

Berdasarkan pengolahan data menggunakan PLS, nilai koefisien determinasi yang dihasilkan Goodness of Fit pada model PLS dapat diketahui dari nilai $\mathrm{R}^{2}$. Semakin tinggi nilai $\mathrm{R}^{2}$ maka dapat dikatakan bahwa model semakin fit dengan data. Nilai $\mathrm{R}^{2}$ menunjukkan konstruk WB sebesar 0.537894 artinya besarnya pengaruh KPS, MA, PES, POP, dan PS terhadap WB sebesar $53.79 \%$.

2. Uji Kausalitas

Hasil pengujian hipotesis dapat diperoleh dengan cara membandingkan nilai $\mathrm{t}$ statistic dengan standar yang telah ditetapkan yaitu 1.96. Hasil statistik menunjukkan bahwa hanya variabel Perilaku Etis Satuan Pengawasan Internal (PES) yang berkorelasi signifikan dengan Whistle Blower (WB). Hal ini dapat dilihat dari hasil $\mathrm{t}$ statistic yang menunjukkan angka di atas 1.96. Untuk variabel Kompetensi Auditor Internal (KPS), Moralitas Auditor Internal (MA), Peran Organisasi Profesi (POP), dan Perlindungan Saksi (PS) memiliki nilai $\mathrm{t}$ statistic kurang dari 1.96 sehingga keempat variabel tersebut memiliki hubungan korelasi yang tidak signifikan terhadap Whistle Blower (WB). Hasil pengujian disajikan dalam tabel 6 .

Pengaruh Kompetensi Auditor internal (KPS) terhadap Whistle Blower (WB). Dari hasil statistik diketahui bahwa variabel KPS tidak memiliki pengaruh terhadap WB. 
Tabel 4

Cross Loadings

\begin{tabular}{|c|c|c|c|c|c|c|}
\hline & KPS & MA & PES & POP & PS & WB \\
\hline KPS10 & 0.856099 & 0.397600 & 0.735726 & 0.628858 & 0.646047 & 0.517678 \\
\hline KPS11 & 0.859401 & 0.530648 & 0.762140 & 0.635820 & 0.672591 & 0.535924 \\
\hline KPS12 & 0.883351 & 0.468100 & 0.743981 & 0.608041 & 0.706907 & 0.539722 \\
\hline KPS13 & 0.930689 & 0.501756 & 0.811970 & 0.630365 & 0.742036 & 0.481030 \\
\hline KPS14 & 0.731693 & 0.277554 & 0.566178 & 0.483800 & 0.503425 & 0.334487 \\
\hline MA15 & 0.451882 & 0.906893 & 0.461287 & 0.505290 & 0.606467 & 0.275497 \\
\hline MA16 & 0.40 & 5 & 035 & 6 & 394 & 0.352301 \\
\hline MA17 & 0.419848 & 0.899670 & 0.420253 & 0.439527 & 0.571015 & 0.325353 \\
\hline MA18 & 0.483828 & 0.822905 & 0.450113 & 0.515853 & 0.666373 & 0.362069 \\
\hline MA19 & 0.329728 & 0.611964 & 0.357504 & 0.408348 & 0.473196 & 0.198242 \\
\hline MA20 & 0.454795 & 0.769618 & 0.479392 & 0.521044 & 0.596261 & 0.311034 \\
\hline PES6 & 0.723003 & 0.459842 & 0.907820 & 0.646559 & 0.647930 & 0.762688 \\
\hline PES7 & 0.839307 & 0.531274 & 0.957981 & 0.758585 & 0.762511 & 0.629483 \\
\hline PES8 & 0.831327 & 0.503362 & 0.944451 & 0.703606 & 0.732502 & 0.626232 \\
\hline PES9 & 0.798781 & 0.463289 & 0.913796 & 0.679629 & 0.720106 & 0.632658 \\
\hline POP1 & 0.702609 & 0.606934 & 0.743609 & 0.898262 & 0.751375 & 0.523898 \\
\hline POP2 & 0.722231 & 0.560829 & 0.755653 & 0.917757 & 0.750237 & 0.553497 \\
\hline POP3 & 0.521885 & 0.438559 & 0.598123 & 0.838191 & 0.562898 & 0.555999 \\
\hline POP4 & 0.526750 & 0.441556 & 0.561568 & 0.842789 & 0.587881 & 0.455095 \\
\hline POP5 & 0.557316 & 0.476868 & 0.552503 & 0.821899 & 5166 & 0.494907 \\
\hline PS10 & 0.685802 & 0.607690 & 0.688905 & 0.705681 & 0.921077 & 0.469411 \\
\hline PS6 & 0.669443 & 0.746253 & 0.640589 & 0.734836 & 0.875063 & 0.429028 \\
\hline PS7 & 0.754030 & 0.676510 & 0.746765 & 0.704262 & 0.979208 & 0.514753 \\
\hline PS8 & 0.780672 & 0.631695 & 0.764502 & 0.668546 & 0.951441 & 0.514747 \\
\hline PS9 & 0.716195 & 0.648742 & 0.731578 & 0.671806 & 0.944560 & 0.514765 \\
\hline WB1 & 0.439078 & 0.310043 & 0.623938 & 0.556994 & 0.428635 & 0.835877 \\
\hline WB2 & 0.427653 & 0.181659 & 0.500072 & 0.363767 & 0.344582 & 0.792558 \\
\hline WB3 & 0.413005 & 0.273104 & 0.440884 & 0.400018 & 0.315638 & 0.755210 \\
\hline WB4 & 0.427806 & 0.317855 & 0.556131 & 0.487719 & 0.448016 & 0.786337 \\
\hline WB5 & 0.511376 & 0.362519 & 0.623775 & 0.483290 & 0.465753 & 0.714700 \\
\hline
\end{tabular}


Tabel 5

Latent Variable Correlations

\begin{tabular}{|c|c|c|c|c|c|c|}
\hline & KPS & MA & PES & POP & PS & WB \\
\hline KPS & \multicolumn{6}{|l|}{1.000000} \\
\hline MA & \multicolumn{6}{|c|}{0.5195771 .000000} \\
\hline PES & \multicolumn{6}{|c|}{0.8542510 .5247381 .000000} \\
\hline POP & \multicolumn{6}{|c|}{0.7040770 .5857850 .7469561} \\
\hline PS & \multicolumn{6}{|c|}{049370.7661130 .7426271 .000000} \\
\hline WB & \multicolumn{6}{|c|}{ 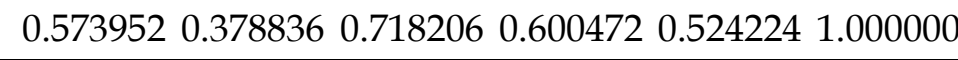 } \\
\hline & & \multicolumn{2}{|c|}{ AVE } & \multicolumn{3}{|c|}{ Akar AVE } \\
\hline \multicolumn{2}{|c|}{ KPS } & \multicolumn{2}{|c|}{0.730668} & \multicolumn{3}{|c|}{0.854791} \\
\hline \multicolumn{2}{|c|}{ MA } & \multicolumn{2}{|c|}{0.676139} & \multicolumn{3}{|c|}{0.822277} \\
\hline \multicolumn{2}{|c|}{ PES } & \multicolumn{2}{|c|}{0.867219} & \multicolumn{3}{|c|}{0.931245} \\
\hline \multicolumn{2}{|c|}{ POP } & \multicolumn{2}{|c|}{0.747506} & \multicolumn{3}{|c|}{0.864584} \\
\hline \multicolumn{2}{|r|}{ PS } & \multicolumn{2}{|c|}{0.874080} & \multicolumn{3}{|c|}{0.934922} \\
\hline \multicolumn{2}{|r|}{ WB } & \multicolumn{2}{|c|}{0.605260} & \multicolumn{3}{|c|}{0.777984} \\
\hline
\end{tabular}

Tabel 6

Path Coefficients (Mean, STDEV, T-Values)

\begin{tabular}{lccccc}
\hline \hline & $\begin{array}{c}\text { Original } \\
\text { Sample (O) }\end{array}$ & $\begin{array}{c}\text { Sample Mean } \\
\mathbf{( M )}\end{array}$ & $\begin{array}{c}\text { Standard } \\
\text { Deviation } \\
\text { (STDEV) }\end{array}$ & $\begin{array}{c}\text { Standard } \\
\text { Error (STERR) }\end{array}$ & $\begin{array}{c}\text { T Statistics } \\
(\mid \text { O/STERR |) }\end{array}$ \\
\hline KPS -> WB & -0.150363 & -0.104499 & 0.217173 & 0.217173 & 0.692365 \\
MA -> WB & 0.008973 & 0.018412 & 0.097525 & 0.097525 & 0.092008 \\
PES -> WB & 0.773327 & 0.696015 & 0.277112 & 0.277112 & 2.790669 \\
POP -> WB & 0.206302 & 0.247091 & 0.130107 & 0.130107 & 1.585628 \\
PS -> WB & -0.111577 & -0.103935 & 0.144300 & 0.144300 & 0.773231 \\
\hline
\end{tabular}

Hal ini ditunjukkan oleh nilai koefisien jalur sebesar -0.150363 dan nilai $\mathrm{t}$ statistic sebesar 0.692365 kurang dari 1.96. Temuan ini menunjukkan bahwa seorang auditor internal yang berkehendak menjadi Whistle Blower tidak tergantung dari apakah seorang auditor internal tersebut memiliki kompetensi atau keahlian yang memadai. Auditor internal yang tidak memahami atau tidak ahli pun dapat menjadi Whistle Blower. Yang penting adalah kemauan dari auditor internal tersebut untuk mengungkap ke- jahatan yang terjadi di organisasinya. Temuan ini berbeda dengan pendapat Lezar dan Spaeth (2002) yang menyatakan bahwa seseorang berkehendak menjadi Whistle Blower ini tergantung pada kompetensinya.

Pengaruh Moralitas Auditor Internal (MA) terhadap Whistle Blower (WB). Dari hasil statistik dapat diketahui bahwa variabel MA tidak memiliki pengaruh terhadap WB. Hal ini ditunjukkan oleh nilai koefisien jalur sebesar 0.008973 dan nilai $\mathrm{t}$ statistic sebesar 0.092008 kurang dari 1.96. 
Temuan ini menunjukkan bahwa seorang auditor internal menjadi Whistle Blower itu tidak tergantung dari apakah seseorang itu memiliki sikap moral yang memadai atau tidak. Meski sikap moralnya tidak atau kurang baik seorang auditor internal dapat menjadi Whistle Blower. Hal ini dimungkinkan karena sebagian besar kejahatan kerah putih atau fraud dilakukan secara kolutif. Seringkali seseorang yang terlibat dalam kejahatan tersebut mau atau bersedia mengungkap keberadaan kejahatan tersebut karena dijanjikan keringanan hukuman bila bersedia mengungkap fakta kejahatan yang sebenarnya yang jauh lebih besar dari dugaan atau sangkaan permulaan. Hasil temuan ini berbeda dengan pendapat Kohlberg (1969) dan Rest (1979) yang menyatakan bahwa seseorang berkehendak menjadi Whistle Blower ini tergantung pada moralitas yang dimiliki.

Pengaruh Perilaku Etis Satuan Pengawasan Internal (PES) terhadap Whistle Blower (WB). Dari hasil statistik dapat diketahui bahwa variabel PES memiliki pengaruh positif dan signifikan terhadap WB. Hal ini ditunjukkan oleh nilai koefisien jalur sebesar 0.773327 yang bertanda positif dan signifikan pada alpha $5 \%$ yang ditunjukkan oleh nilai $\mathrm{t}$ statistic sebesar 2.790669 yang lebih dari 1.96 .

Temuan ini menunjukkan bahwa perilaku etis yang dimiliki oleh auditor internal atau satuan pengawasan internal mempengaruhi sikap dan niat untuk menjadi Whistle Blower. Temuan ini mendukung temuan Wilopo (2006) yang menyatakan bahwa perilaku etis atau tidak etis dari auditor internal akan memberi pengaruh terhadap kecenderungan kejahatan yang dilakukan oleh para auditor internal dalam bentuk kecurangan auditor internal. Demikian pula temuan ini mendukung hasil penelitian Robinson dan Bennet (1995) serta Tang dan Chiu (2003) yang menyatakan bahwa perilaku etis adalah perilaku yang tidak menyalahgunakan kedudukan/posisi, perilaku yang tidak menyalahgunakan kekuasaan, perilaku yang tidak menyalah- gunakan sumber daya organisasi, serta perilaku yang peduli terhadap kondisi perusahaan. Pengaruh Peran Organisasi Profesi (POP) terhadap Whistle Blower (WB). Dari hasil statistik dapat diketahui bahwa variabel POP tidak memiliki pengaruh terhadap WB. Hal ini ditunjukkan oleh nilai koefisien jalur sebesar 0.206302 dan nilai $t$ statistic sebesar 1.585628 kurang dari 1.96.

Temuan ini menunjukkan bahwa para auditor internal atau satuan pengawasan internal tidak atau kurang mempercayai organisasi profesinya akan berperan untuk memberi perlindungan bila seorang auditor internal mengungkap kejahatan yang terjadi di perusahaan atau organisasi tempat dia bekerja. Sikap ini dimaklumi karena organisasi profesi di Indonesia belum benar-benar menjadi organisasi yang profesional yang memiliki perangkat dan sistem yang benarbenar memberi perlindungan bila anggotanya melakukan suatu tindakan yang etis. Sebaliknya, organisasi profesi akan memberi sanksi yang memadai bila anggotanya terlibat dalam suatu kejahatan tertentu. Temuan ini berbeda dengan hasil penelitian dari Kleckner dan Jackson (2004) yang menyatakan bahwa organisasi profesi akan memberi perlindungan kepada anggotanya, khususnya bila menghadapi permasalahan yang berkaitan dengan sikap etis.

Pengaruh Perlindungan Saksi (PS) terhadap Whistle Blower (WB). Dari hasil statistik dapat diketahui bahwa variabel PS tidak memiliki pengaruh terhadap WB. Hal ini ditunjukkan oleh nilai koefisien jalur sebesar -0.111577 dan nilai t statistic sebesar 0.773231 kurang dari 1.96 .

Temuan ini menunjukkan bahwa para auditor internal tidak yakin bahwa lembaga perlindungan saksi akan memberi perlindungan bila mereka menjadi Whistle Blower. Hal ini karena dalam faktanya meski Indonesia sudah memiliki undang-undang tentang perlindungan saksi, namun dalam kenyataannya banyak kejadian yang seseorang berani mengungkap suatu kejahatan tertentu serta menjadi saksi di pengadilan akan dipersalahkan atau dituntut tindak 
pidana untuk perkara tersebut atau perkaraperkara yang lain. Temuan ini berbeda dengan hasil penelitian Kleckner dan Jackson (2004) yang menyatakan bahwa lembaga perlindungan saksi akan memberi perlindungan kepada anggotanya, khususnya bila menghadapi permasalahan yang berkaitan dengan sikap etis.

Perancangan dan implementasi Sistem Pengendalian Intern (SPI) merupakan tanggung jawab manajemen. Pada sudut pandang yang lain, aktivitas operasional yang kompleks menuntut manajemen membutuhkan suatu fungsi/departemen baru yang disebut audit internal. Audit internal merupakan fungsi penilaian independen yang ada di perusahaan untuk memeriksa dan mengevaluasi kegiatan perusahaan sebagai jasa yang diberikan kepada perusahaan. Hasil penelitian ini menunjukkan bahwa dari persepsi auditor internal sebagai pihak yang dianggap berperan untuk mengetahui kejahatan kerah putih atau fraud, seseorang dapat atau mau menjadi Whistle Blower sangat ditentukan oleh perilaku etis dari berbagai pihak dalam perusahaan atau organisasi. Perilaku etis ini termasuk perilaku etis dari manajemen perusahaan untuk bersedia menerima informasi tentang kejahatan kerah putih untuk dilakukan perbaikan. Meski tidak signifikan, dalam berbagai kasus sikap moral dari auditor eksternal berperan dalam menentukan auditor internal untuk menjadi Whistle Blower, sedangkan keberadaan organisasi profesi dari auditor internal, lembaga perlindungan saksi, serta kompetensi auditor internal tidak dianggap perlu bagi auditor internal untuk menjadi seorang Whistle Blower.

\section{SIMPULAN DAN SARAN Simpulan}

Kebijakan Whistle Blower adalah proses karyawan yang bekerja di perusahaan publik atau swasta mengungkap klaim malpraktek dalam organisasi (Saha, 2011). Penelitian ini merupakan pengembangan dari penelitian Wilopo dan Nurul (2012).
Penelitian ini bertujuan untuk mengetahui dan menggali faktor-faktor yang berpengaruh terhadap sistem Whistle Blower di Indonesia. Penelitian ini menggali bahwa faktor-faktor yang mempengaruhi sistem whistle blower adalah faktor internal dan eksternal. Faktor internal adalah kompetensi auditor internal, sikap moral auditor internal, dan perilaku etis auditor internal. Sedangkan faktor eksternal adalah peran organisasi profesi auditor internal dan lembaga perlindungan saksi. Hasil pengujian statistik menunjukkan bahwa hanya perilaku etis auditor internal yang berpengaruh signifikan terhadap sistem whistle blower di Indonesia. Sikap moral dari auditor eksternal dalam berbagai kasus juga berperan dalam menentukan dan berpengaruh bagi auditor internal untuk menjadi whistle blower. Sedangkan faktor-faktor yang lain tidak berpengaruh secara signifikan. Hasil ini merupakan pengembangan dari penelitian yang dilakukan Wilopo dan Nurul (2012) yang menemukan bahwa untuk mengembangkan corporate governance di Indonesia diperlukan sistem whistle blower yang dipengaruhi dan ditentukan oleh keberadaan lembaga perlindungan saksi. Hasil penelitian ini menunjukkan bahwa sistem whistle blower ini hanya dapat dikembangkan di Indonesia bila auditor internal memiliki perilaku yang etis serta sikap moral yang baik.

\section{Saran}

Penelitian tentang whistle blower merupakan topik penelitian yang relatif belum banyak dilakukan di Indonesia. Di samping itu di Indonesia sistem whistle blower masih belum banyak diterapkan di dalam perusahaan ataupun organisasi-organisasi pemerintahan dan lainnya. Sampai dengan saat ini Indonesia juga belum memiliki Undang-Undang tentang whistle blower. Oleh karena itu penelitian selanjutnya sebaiknya mengembangkan model penelitian yang lebih komprehensif mengenai whistle blower. 


\section{DAFTAR PUSTAKA}

Antara. 2008. Revisi Undang-Undang Pencucian Uang Perluas Wewenang PPATK.

Association of Certified Fraud Examiners. 2012. Report to the Nations.

Baker, N. 2008. See no evil, hear no evil, speak no evil. Internal Auditor, April: 39-43.

Bouville, M. 2008. Whistle Blowing and Morality. Journal of Business Ethics. 2008, springer.

Copeer, D. R. dan C. W. Emory. 1995. Business Research Methods. Chicago: Irwin.

Das, S. G. dan R. Aldrin. 2007. WhistleBlowing and Competitive Advantage. Journal of Indian Management, AprilJune 2007, Cochin, India.

Dworkin, T. M. 2007. SOX and Whistleblowing. Michigan Law Review. June (105): 1757-1780.

Heyes, A. G. dan S. Kapur. 2009. An Economic Model of Whistle Blower Policy. The Journal of Law, Economics and Organization 25(1): 157-182.

Ikatan Auditor Internal Indonesia. 1998. Kode Etik Ikatan Auditor internal Indonesia.

Ghozali, I. 2012. Structural Equation Modeling: Metode Alternatif dengan Partial Least Square (Edisi 3). Semarang: Badan penerbit Universitas Diponegoro.

Institut Akuntan Publik Indonesia (IAPI). 2009. Daftar Pembelajaran Profesional Lanjutan untuk tahun 2009. Download dari situs www.iapi.or.id

International Chamber of Commerce (ICC). 2008. ICC Guidelines on Whistleblowing.

Lezar, T. dan M. Spaeth. 2002. Blowing the Whistle. Risk Management, April.

Kerlinger, F. N. 1986. Foundations of behavioral research (3rd Ed.). New York: Holt, Rinehart and Winston.

Kleckner dan Jackson. 2004. Sarbanes-Oxley and the Whistle-Blower Protections. The CP Journal.

Kohlberg, L. 1969. Stage and Sequence: The Cognitive - Development Approach
Moral Action to Socialization. In D.A. Goslin (Ed). Handbook of socialization theory and research. Chicago: RandMcNally: 347-480.

Malhotra, N. K. 2010. Marketing Research: an applied orientation (6 $6^{\text {th }} \mathrm{Ed}$.). New Jersey: Prentice Hall.

Mansbach, A. 2007. Political Surplus of whistleblowing: a case study. Business Ethics: a European Review April 16(2): 124-131.

McKoy, D. V. 2012. Whistle Blowing and the Law. Working Paper.

Media Pertamina, 2008. Whistle Blower, Pengingat Kita agar Tidak Korupsi. Edisi No. 33, Tahun XLIV, 18 Agustus.

Rest, J. 1979. Developing in Judging Moral Issues. Menneapolis, MN: University of Minnesota Press.

Richardson S. dan B. Richardson. 2007. The Accountant as Whisleblower. The Indonesian Accounting Society.

Robinson, S. L. dan R. J. Bennet. 1995. A Typology of Deviant worksplace Behaviors: A Multidimensional Scaling Study. Academy of Management Journal 18(2): 555-572.

Saha, O. 2011. Whistle Blower Policy. Working Paper.

Saleh, A. O. 2008. Perlindungan bagi Whistle blower. Tempo Interaktif, 26 September.

Tang T. L. P. dan R. K. Chiu. 2003. Income, Money Etic, Pay Satisfaction, Commitment, and Unetichical Behavior: Is the Love of Money the Root of Evil for Hong Kong Emplyees? Journal of Business Ethics 46: 13-20.

Tempo Interaktif. 2008. Perlindungan bagi Whistle blower. 26 September.

Undang-Undang Republik Indonesia No. 20. 2001. Perubahan atas UndangUndang No. 31 tahun 1999 tentang Pemberantasan Tindak Pidana Korupsi.

Undang-Undang Republik Indonesia No. 13. 2006. Undang-Undang tentang Perlindungan Saksi dan Korban.

Undang-Undang Republik Indonesia No. 8. 2010. Perubahan atas Undang-Undang 
258 Ekuitas: Jurnal Ekonomi dan Keuangan - Volume 18, Nomor 2, Juni 2014 : 242 - 258

No. 15 tahun 2002 tentang Tindak Pidana Pencucian Uang.

Verschoor, C. C. 2002. A reader responds to ethics of Enron whistle blower. Strategic Finance, Agust.

Wilopo, 2006. Analisis Faktor-Faktor yang Berpengaruh terhadap Kecenderungan Kecurangan Auditor Internal: Studi pada Perusahaan Publik dan Badan
Usaha Milik Negara di Indonesia. Jurnal Riset Akuntansi Indonesia 9(3): September.

Wilopo dan Nurul. 2012. The Effectiveness of Whistle Blower in Improving Corporate Governance. Proceeding of $2^{\text {nd }}$ Accounting Research and Education Conference (AREC 2012) Universiti Teknologi Mara, Malaysia. 